\title{
O CURSO DE ORGANIZAÇÃO DE MUSEUS ESCOLARES DO MUSEU HISTÓRICO NACIONAL (BRASIL, 1958)
}

\author{
Ana Carolina Gelmini de Faria ${ }^{1}$ \\ Zita Rosane Possamai
}

\section{RESUMO}

O artigo aborda o Curso de Organização dos Museus Escolares realizado pelo Museu Histórico Nacional a convite do Instituto Nacional de Estudos e Pesquisas Educacionais (Inep), no ano de 1958. O acordo entre as duas instituições visou ministrar um curso de curta-duração destinado a professoras-bolsistas, a fim de capacitá-las a organizarem museus escolares em seus estados de procedência. A formação abarcou os conteúdos de organização, arrumação, catalogação e classificação aplicada a museus. O estudo foi realizado na perspectiva da história da educação e da história dos museus. Foram consultados os relatórios do Museu Histórico Nacional, os escritos das alunas do curso e dos servidores do Museu, bem como a produção museológica brasileira e internacional do contexto. Foi possível identificar um diálogo entre os sujeitos vinculados à educação escolar e aos museus, no qual estavam em debate representações, definições,

${ }^{1}$ Universidade Federal do Rio Grande do Sul (UFRGS), Porto Alegre/RS, Brasil.

${ }^{2}$ Universidade Federal do Rio Grande do Sul (UFRGS), Porto Alegre/RS, Brasil. 
apropriações e práticas sobre os museus. O estudo permitiu alargar o conhecimento sobre os museus escolares, sobre a atuação educativa do Museu Histórico Nacional e sobre as circulações internacionais no contexto em questão.

Palavras-chave: Curso de Organização dos Museus Escolares, Museu Histórico Nacional, Instituto Nacional de Estudos e Pesquisas Educacionais (Inep), história dos museus.

\section{EL CURSO DE ORGANIZACIÓN DE MUSEOS ESCOLARES DEL MUSEO HISTÓRICO NACIONAL (BRASIL, 1958)}

\section{RESUMEN}

El presente artículo aborda la organización por el Museo Histórico Nacional del Curso de Organización de Museos Escolares por invitación del Instituto Nacional de Estudios y Pesquisas Educacionales (Inep), en el año de 1958. El acuerdo entre las dos instituciones pretendía administrar un curso de corta duración destinado a profesoras becadas, con el fin de capacitarlas para organizar museos escolares en sus estados de origen. La formación incluía los contenidos de organización, catalogación y clasificación aplicada a museos. El estudio fue realizado desde la perspectiva de la historia de la educación y de la historia de los museos. Fueron consultados las relatorías del Museo Histórico Nacional, los escritos de las alumnas del curso y de los servidores del museo, así como la producción museológica brasileña e internacional del momento. Fue posible identificar un diálogo entre los sujetos vinculados a la educación escolar y a los museos, dejando como ejes centrales del debate las representaciones, definiciones, apropiaciones y prácticas sobre los museos. El estudio permitió extender el conocimiento sobre los museos escolares, sobre la actuación educativa del Museo Histórico Nacional y sobre las circulaciones internacionales en este período.

Palabras clave: Curso de Organización de los Museos Escolares; Museo Histórico Nacional; Instituto Nacional de Estudios y Pesquisas Educacionales, historia de los museos.

\section{THE ORGANIZATION OF SCHOOL MUSEUMS COURSE BY THE HISTORICAL NATIONAL MUSEUM (BRASIL, 1958)}

\section{ABSTRACT}

This article is about the Organization of School Museums Course by the Historical National Museum of Brazil, as invited by the National Institute of Educational Studies and Research Instituto Nacional de Estudos e Pesquisas Educacionais (Inep) in 1958. The agreement between both institutions aimed at offering a short course to scholarship holder teachers in order to enable them to organize school museums in their original states. Reports of the Historical National Museum of Brazil and of its employees, the students' written assessments, and the Brazilian and international museological studies of the context were consulted. It was possible to recognize a 
dialogue between teachers and professionals of the museums in which representations, definitions, appropriations and practices about museums are being discussed. This paper has increased knowledge on school museums, educational performance of the Historical National Museum and international circulation in this context.

Keywords: Organization of School Museums Course, Historical National Museum of Brazil, National Institute of Educational Studies and Research (Inep), history of museums.

\section{COURS D'ORGANISATION DES MUSÉES SCOLAIRES DU MUSÉE HISTORIQUE NATIONAL (BRÉSIL, 1958)}

\section{RÉSUMÉ}

Cet article étude l'organisation par le Musée Historique National du Brésil du Cours d'Organisation des Musées Scolaires, invité par le Institut National des Études et Recherches Éducatifs (Inep), 1958. L'entente entre les deux institutions a eu l'objectif d'offrir une formation pour les enseignants apprendre à organiser musées scolaires, dans ses provinces. L'étude a été realisé dans le domaine de l'histoire de l'éducation et d'histoire des musées. Les sources analysées ont été des rapports du musée, les écrits des élèves du cours et des fonctionnaires du musée et les études muséologiques brésiliens et internationaux. Ce cas permet de voir un dialogue entre les enseignants et les profissionnels du musée et un débat à propos des représentations, apropriations et pratiques du musée.

Mots-clés: Cours d'Organisation des Musées Scolaires, Musée Historique National du Brésil, Institut National des Études et Recherches Educatifs (Inep), histoire des musées. 


\section{INTRODUÇÃO}

Os museus escolares e pedagógicos constituíram-se em estratégias relevantes para a implantação dos sistemas públicos de ensino e para o aperfeiçoamento da educação escolar, especialmente a partir do século XIX. Nesse sentido, vem sendo investigados no âmbito da História da Educação em diversos países (BERRIO, 2000; FONTAINE; MATASCI, 2015; LINARES, 2012), incluindo o Brasil (PETRY, 2013; POSSAMAI, 2015a; VIDAL, 1999). Podem ser compreendidos a partir de uma categoria mais ampla, denominada de museus de educação (POSSAMAI, 2015), na qual estão inseridos os materiais didáticos produzidos no âmbito do método intuitivo (VIDAL, 2012); os museus estabelecidos em espaços escolares (PETRY, 2013); os museus pedagógicos nacionais ${ }^{3}$, fundados por diferentes nações com o objetivo de oferecer um espaço institucionalizado de apoio à implantação da escola pública (BASTOS, 2002; POSSAMAI, 2015a).

Ao restringir o foco da análise para os limites desse artigo, os estudos demonstram que museus escolares constituiu-se em expressão polissêmica ao designar uma variedade de materiais e espaços configurados a partir de diversas práticas, cujo ponto de inflexão era o apoio ao ensino calcado no estímulo dos sentidos, com ênfase na visão, de modo a reforçar uma pedagogia do olhar para chegar à intelecção. Nessa perspectiva, foram produzidas por empresas especializadas coleções de quadros murais, com imagens de fenômenos da natureza e processos da manufatura e caixas didáticas com amostras de materiais provenientes da natureza ou da indústria (GARCÍA, 2007; VIDAL, 2012). As práticas criativas de mestres e estudantes geraram, por sua vez, outros formatos de museus escolares, como coleções de maquetes e amostras, armários, vitrines

\footnotetext{
3 O Brasil também teve o seu museu pedagógico nacional, denominado por Pedagogium e inaugurado na capital federal em 1890. Segundo Bastos, este se constituía como um "[...] centro impulsor de reformas e melhoramentos de que necessitava a educação nacional, [...] expondo o que de mais moderno houvesse quanto aos métodos e ao material de ensino" (BASTOS, 2002, p. 278). A autora aponta que o Pedagogium teve uma institucionalização instável, marcada por ameaças de extinção, falta de definição orçamentária e dependência política. Em 1898, foi extinto e no mesmo ano reaberto. Em 1919 foi extinto definitivamente. Ver ainda Mignot (2013).
} 
dispostas em corredores, pequenas salas ou até mesmo museus de ciências naturais no interior das instituições (PETRY, 2013; POSSAMAI; PAZ, 2017; WITT; POSSAMAI, 2016).

No Brasil, no mesmo contexto de busca por uma educação calcada nos princípios científicos configurava-se o movimento dos museus de história natural (LOPES, 2005; SANJAD, 2011; SCHWARTZ, 2005). Desse modo, entre fins do século XIX e primeiras décadas do século XX, a escola encontrou nos museus de ciências coleções e conhecimentos necessários a um adequado desenvolvimento dos saberes curriculares. Em vários estados brasileiros, os museus contribuíram com as escolas e com o ensino. O Museu Nacional (LOPES, 1997) estabelecia uma relação de cooperação com as escolas do Rio de Janeiro e destinou parte de suas dependências para criar um museu escolar de história natural, destinado especialmente à aprendizagem das crianças (Ibid.). Além disso, a partir de 1919 o Museu Nacional passou a confeccionar quadros murais e coleções didáticas sobre as ciências naturais do Brasil destinadas a todas os estabelecimentos de ensino do País (SILY, 2008). O Museu do Estado do Rio Grande do Sul fora convidado a colaborar com as escolas através da confecção de 1000 "coleções escolares”, cada uma delas composta por 110 exemplares de rochas, minerais e amostras de solos do estado (POSSAMAI, 2012). O Museu Paulista também contribuiu com o envio de museus escolares e objetos para as escolas do estado de São Paulo (SILVA; BRAGHINI, 2017).

Nesse sentido, ao longo do século XX, o diálogo entre as escolas e os museus se fortaleceu, especialmente a partir da configuração dos departamentos educativos nas instituições museológicas. Os estudantes não eram apenas público cativo dos museus, mas estes foram buscados para assessorar processos educativos de sua competência específica, como era o caso da formação e gestão de coleções e de espaços museológicos no interior das escolas. Daí os museus serem requisitados para auxiliar professores e professoras na formação de museus escolares, conforme ocorreu com o curso de Organização dos Museus Escolares do Museu Histórico Nacional. 
Os documentos produzidos pelo Museu Histórico Nacional e seus servidores, os escritos das alunas bolsistas do curso, a produção museológica brasileira e internacional permitiu investigar o diálogo entre os sujeitos vinculados à educação escolar e aos museus, no qual estão em debate representações, definições, apropriações e práticas das instituições museais. Esse artigo se propõe analisar, a partir da documentação localizada no Arquivo Institucional do Museu Histórico Nacional, a concepção, desenvolvimento e impressões do Curso de Organização dos Museus Escolares, que foi uma edição adaptada do Curso de Museus ${ }^{4}$ para professoras de diferentes estados brasileiros.

Realizado em 1958, o curso de curta-duração tinha por proposta qualificar as professoras no que tange à atuação de conservadores de museus atualmente profissão designada como museólogo(a) - aplicada à realidade dos museus escolares da época. A pesquisa valeu-se de documentos produzidos pelos envolvidos nesse processo: relatórios institucionais elaborados pelos ministrantes do Curso de Organização dos Museus Escolares; avaliação final das quatro professoras-bolsistas designadas pelo Instituto Nacional de Estudos e Pesquisas Educacionais (Inep), e o trabalho final de três dessas participantes, além de documentos produzidos na conjuntura da realização do Curso, como o relatório do Seminário Regional Latino-Americano de Museus promovido pela Organização das Nações Unidas para a Educação, a Ciência e a Cultura (Unesco), evento que as professoras-bolsistas participaram como observadoras, e livros publicados sobre educação em museus por conservadores de museus no período, que contribuem para compreender o cenário dos museus escolares pelas impressões desses profissionais.

Na profícua interface entre a história dos museus e a história da educação (POSSAMAI, 2015b), o estudo orientou-se nos aportes da história cultural (VIÑAO FRAGO, 1995) e amparou-se em corpus documental necessário para

\footnotetext{
4 O Curso de Museus, fundado em 1932 no Museu Histórico Nacional, visava formar profissionais especializados para o trabalho nos museus com o título de conservadores de museus. Somente em 1966 que esses formandos passaram a ser oficialmente intitulados de museólogos, conforme o artigo $3^{\circ}$ do Decreto n. 58.800 de 13 de julho de 1966.
} 
uma escrita da história (CERTEAU, 2011). Nessa perspectiva, a imersão na documentação balizou-se pela busca de pistas, sinais e indícios (GINZBURG, 1989) de forma a elaborar uma narrativa que permitisse alargar o conhecimento sobre os museus escolares brasileiros, sobre a atuação educativa do Museu Histórico Nacional e sobre o debate nacional e internacional do tema em questão na década de 1950.

\section{O CURSO DE ORGANIZAÇÃO DOS MUSEUS ESCOLARES DO MUSEU HISTÓRICO NACIONAL}

O diálogo entre educação e museus encontrou um impulso substantivo nos anos 1950, tanto em nível internacional, a partir das iniciativas da Unesco e do Conselho Internacional de Museus (Icom)5, quanto no Brasil, através da atuação e da produção escrita de profissionais vinculados ao campo dos museus. Nesse diálogo, a categoria de museu escolar constituiu-se em tema de estudo e formação que proporcionou a circulação de saberes e propostas metodológicas.

Desse modo, museus escolares e museus pedagógicos eram expressões recorrentes na produção do campo dos museus da década de 1950. Os museus escolares eram sinalizados por profissionais de museus como um recurso a ser aplicado em comunidades regionais que, pela distância geográfica, tinham dificuldades de promoverem visitações aos museus das capitais (REAL, 1958; TRIGUEIROS, 1958). Além disso, os livros produzidos pelos conservadores de museus, nesse período, buscavam diferenciar esses conceitos para o leitor, uma vez que direcionavam o conteúdo pesquisado não somente para seus pares, mas

\footnotetext{
5 Eventos promovidos pela Unesco, com a parceria do Icom nos anos de 1952, 1954 e 1958 sobre educação em museus são exemplos do investimento, em nível internacional, conferido ao tema. Em 1952, ocorreu o Seminário Internacional da Unesco, intitulado Sobre o papel dos museus na educação (Nova York, EUA). O segundo Seminário Internacional da Unesco, de 1954, ocorreu com o mesmo título (Atenas, Grécia). No ano de 1958, foi promovido o Seminário Regional Latino-Americano da Unesco, nomeado A Função Educativa dos Museus (Rio de Janeiro, Brasil) (FARIA, 2017).
} 
também para a comunidade escolar (FARIA, 2013).

De acordo com o conservador de museus Florisvaldo dos Santos Trigueiros, em seu livro Museu e Educação (1958), o museu escolar teria como público alvo as crianças e o enfoque do acervo voltar-se-ia para a assistência das disciplinas cursadas nas escolas, possibilitando aos professores outras abordagens de ensino. Já o museu pedagógico teria como público-alvo os professores e suas coleções, compostas por materiais que representassem o cotidiano escolar e a evolução dos métodos de ensino. O autor lamenta, na publicação, a não existência de um museu desse perfil em vigência no Brasil. Observa-se que o autor corrobora com as diferenciações entre museus escolares e museus pedagógicos, que prevaleciam no Brasil desde o século XIX (VIDAL, 2012).

Trigueiros (1958), ao ter conhecimento de que os museus escolares eram a tipologia de museus mais encontrada na comunidade escolar, buscou em seu livro elencar as características que singularizavam esse tipo de museu: não era destinado à visitação pública; o manuseio do objeto deveria ser estimulado, ainda que provocasse sua destruição; a própria comunidade escolar era incentivada a doar acervos e selecionar os de contribuição pedagógica. O espaço destinado ao museu deveria ser harmonioso, com vitrines e painéis correspondentes à altura dos estudantes, valorização dos objetos, etiquetas escritas com clareza, utilização de plantas para alegrar o ambiente (tornando-se ao mesmo tempo objeto de estudo) e recursos audiovisuais (TRIGUEIROS, 1958). De acordo com o autor, "[...] o tempo de museu-bazar já passou” (Ibid., p. 116), devendo o museu estimular as questões: Como? Onde? Por quê?

Nesse contexto, em 1958, o Museu Histórico Nacional foi convidado pelo Inep a ministrar um Curso de Organização dos Museus Escolares, experiência inédita na programação da instituição. Nesse ano, o Museu já tinha alcançado sua estabilidade após exatos 36 anos de existência. Segundo informações do relatório anual de 1958, a instituição recebera 20.139 visitantes e distribuíra para instituições culturais e afins, do país e do exterior, 701 exemplares de publicações 
vinculadas ao Museu, além de propiciar oito bolsas de estudos para o Curso de Museus, mantendo uma rede de contatos e trocas de informações (BRASIL, 1959).

Nesse ano, o Curso de Museus e o Inep fizeram um acordo para ministrar um curso de curta-duração com objetivo de possibilitar que professoras-bolsistas daquele instituto estudassem e estagiassem no Museu, no período de seis meses, a fim de capacitá-las a organizarem, em seus estados de procedência, museus escolares. Segundo Octavia Corrêa dos Santos Oliveira ${ }^{6}$, professora na época da disciplina Técnica de Museus do Curso de Museus e chefe da $1^{a}$ Seção - História do Museu Histórico Nacional, a organização de um programa para receber as professoras-bolsistas apresentou dificuldades, pois a equipe do Museu não tinha certeza quanto à finalidade do estágio (BRASIL, 1958a).

Octavia Corrêa relata em documento encaminhado em 18 de novembro de 1958 à coordenadora do Curso de Museus, Nair de Moraes Carvalho7, que na cidade do Rio de Janeiro não existiam museus escolares no sentido estrito da palavra, tendo como experiência mais aproximada a do Museu da Cidade do Rio de Janeiro, que buscou organizar um museu de caráter escolar, mas que suspendeu o projeto devido à ampliação de seu acervo sobre a cidade, consolidando outro perfil institucional. A funcionária levantou como uma possibilidade da solicitação do curso de curta-duração a organização de museus pedagógicos e didáticos no próprio Inep, projeto que até aquele momento não tinha sido concretizado (BRASIL, 1958a).

${ }^{6}$ Octavia Corrêa dos Santos Oliveira matriculou-se no Curso de Museus em 1936, sendo diplomada em 1938. Foi classificada no primeiro concurso realizado pelo Departamento Administrativo do Serviço Público (Dasp) em 1939-1940 para conservador de museus atuando, entre vários setores, na Seção de História do Museu Histórico Nacional. Tornou-se coordenadora interina do Curso de Museus em vários períodos (SÁ; SIQUEIRA, 2007).

7 Nair de Moraes Carvalho matriculou-se no Curso de Museus em 1935, sendo diplomada em 1936. Funcionária do Museu Histórico Nacional desde 1937, foi professora do Curso de Museus e a primeira coordenadora do Curso, atuando nessa função de 1944 até 1967 (SÁ; SIQUEIRA, 2007). Nair de Moraes Carvalho apresentou duas ênfases no trabalho educativo desenvolvido no Museu Histórico Nacional: as visitas guiadas e o Curso de Museus, publicando sobre ambos os temas. 
Ainda que Octavia Corrêa expusesse no documento uma dúvida sobre a finalidade do curso de curta-duração requisitado pelo Inep, a conservadora de museus descreveu que, após diversos debates entre professores, técnicos do Museu Histórico Nacional e estudantes matriculados no Curso de Museus, foi elaborada uma programação contemplando a organização, arrumação, catalogação e classificação aplicada a museus que pudesse ser posteriormente posta em prática em museus escolares estaduais (BRASIL, 1958a).

A realização do curso de curta-duração estava prevista para o início do segundo semestre de 1958, mas devido ao atraso da chegada das professorasbolsistas, as aulas só iniciaram no dia 22 de julho na $1^{\text {a }}$ Seção - História do Museu Histórico Nacional. De acordo com outro documento, elaborado pelos conservadores de museus Octavia Corrêa, Yolanda Marcondes Portugal ${ }^{8}$ e Gerardo Alves de Carvalho9 ${ }^{9}$, quatro professoras-bolsistas foram designadas pelo Inep para as aulas teóricas e práticas promovidas: Maria Nadyr de Freitas, do estado do Rio Grande do Sul; Helena Ferreira Camargo, do estado de São Paulo; Eugenia Pereira de Araujo, do estado de Pernambuco; e Amélia Lucas Mattos, do estado da Bahia (CORRÊA; PORTUGAL; CARVALHO, 1958).

As aulas na $1^{\text {a }}$ Seção - História ocorreram sem interrupção até o dia 9 de setembro do mesmo ano. Nesse período, foram ministrados oito dos dez pontos voltados para a técnica de museus (Quadro 1). Octavia Corrêa registrou que, além da execução da parte teórico-metodológica, foram realizadas, com as professorasbolsistas, visitas guiadas em diversos museus do então Distrito Federal e estado do Rio de Janeiro, como o Museu Imperial, localizado em Petrópolis (BRASIL, 1958a).

\footnotetext{
8 Yolanda Marcondes Portugal matriculou-se no Curso de Museus em 1936, sendo diplomada em 1937. Foi classificada no primeiro concurso realizado pelo Dasp em 1939-1940 para conservador de museus. Entre muitas atuações no Museu Histórico Nacional, foi professora de Numismática (SÁ; SIQUEIRA, 2007).

9 Gerardo Alves de Carvalho matriculou-se no Curso de Museus em 1946, sendo diplomado em 1948. Anteriormente, formou-se pela Escola de Medicina e Cirurgia do Rio de Janeiro, em 1942. Professor de Etnografia do Curso de Museus de 1952 a 1974 (SÁ; SIQUEIRA, 2007).
} 
Quadro 1 - Conteúdo do Curso de Organização dos Museus Escolares (1958) organizado pela $1^{\mathrm{a}}$ Seção - História

\begin{tabular}{|l|l|}
\hline \multicolumn{2}{|l|}{ Curso de Organização dos Museus Escolares promovido pelo Curso de Museus } \\
\hline $\mathbf{0 1}$ & Museus e sua significação. Concepção antiga e moderna. \\
\hline $\mathbf{0 2}$ & Finalidade dos mesmos e sua organização. \\
\hline $\mathbf{0 3}$ & $\begin{array}{l}\text { Diferenciações entre museus pedagógicos, museus didáticos, museus escolares e } \\
\text { museus das escolas. }\end{array}$ \\
\hline $\mathbf{0 4}$ & $\begin{array}{l}\text { Divisão dos museus quanto à finalidade: gerais, parciais, federais, estaduais, } \\
\text { municipais, regionais. Museus oficiais e particulares. Coleções de estudo. }\end{array}$ \\
\hline $\mathbf{0 5}$ & Arrumação dos museus oficiais ou particulares. Tipos de vitrines. Coleções. \\
\hline $\mathbf{0 6}$ & $\begin{array}{l}\text { Regras e princípios técnicos. Condições de natureza geral e condições de caráter pessoal } \\
\text { influindo na arrumação. }\end{array}$ \\
\hline $\mathbf{0 7}$ & $\begin{array}{l}\text { Aplicação dessa mesma técnica aos museus escolares, museus pedagógicos, didáticos e } \\
\text { centro áudio-visuais. }\end{array}$ \\
\hline $\mathbf{o 8}$ & Classificação e arrumação segundo o “curriculum” escolar. \\
\hline $\mathbf{0 9}$ & $\begin{array}{l}\text { Classificação das peças conforme a parte especializada da técnica de museus aplicada às } \\
\text { coleções escolares: } \\
\text { a) Reconhecimento das diversas técnicas de pintura e gravura; } \\
\text { b) Noções de cerâmica; } \\
\text { c) Noções de indumentária; } \\
\text { d) Noções de armaria; } \\
\text { e) Noções de viaturas. }\end{array}$ \\
\hline $\mathbf{1 0}$ & Catalogação e etiquetagem. \\
\hline
\end{tabular}

Fonte: Brasil, 1958a, p. 1-2.

A estrutura do conteúdo programático acima oferece-nos pistas de como o Curso de Organização dos Museus Escolares foi desenvolvido. Percebe-se que, por ser um curso de curta-duração, com público-alvo e temática específica, sua concepção perpassava pelo conteúdo do Curso de Museus de forma incipiente, até porque a formação especializada tinha duração de três anos. Ainda assim, percebe-se que as noções ensinadas se concentravam na disciplina Técnica de Museus. É possível agrupar os pontos desenvolvidos em três abordagens: conceituações, arrumação de exposições e classificação do acervo escolar. 
Os quatro primeiros tópicos do conteúdo programático apresentaram às professoras-bolsistas do Inep o conceito de museu e suas finalidades, com enfoque especial nas modalidades de vinculação direta com o universo escolar: museus pedagógicos, museus didáticos, museus escolares e museus das escolas (BRASIL, 1958a). Percebe-se que, à exceção da especificidade de museus, o fluxo do conteúdo assemelhava-se aos dois volumes do livro Introdução à Técnica de Museus (BARROSO, 1951; 1953), publicação de apoio à disciplina Técnica de Museus, que inicia seus ensinamentos com a apresentação das definições básicas - Museu, Museografia, Museologia e Técnica de Museus - para, na sequência, tratar da finalidade dos museus e da sua organização preliminar (Id., 1951).

Os quatro próximos tópicos fixaram-se em princípios técnicos de arrumação de museus. Observa-se que o interesse era voltado para a montagem de exposições, com temáticas específicas, como montagem de vitrines. Dentre o conjunto temático, o sétimo tópico se destaca ao propor o exercício de adaptar as habilidades e competências da arrumação de museus para as experiências de museus escolares, museus pedagógicos, didáticos e centro audiovisuais (BRASIL, 1958a). Os tópicos exclusivos do curso de curta-duração demonstram não somente o esforço das professoras-bolsistas de aproximarem-se do capital científico do campo dos museus, mas também o empenho dos professores em adaptarem o conteúdo das aulas do Curso de Museus para a realidade mais próxima que as participantes poderiam encontrar em seu campo de atuação.

Os três últimos tópicos abordaram a classificação do acervo adaptado ao currículo escolar. Salienta-se que, das treze noções de classificação ensinadas no Curso de Museus ${ }^{10}$, apenas quatro foram aplicadas às coleções escolares: Cerâmica, Indumentária, Armaria e Viaturas, além das diversas técnicas de Pintura e Gravura, abordadas na $3^{\text {a }}$ Série do Curso de Museus - habilitação para museus artísticos ou de Belas Artes (BRASIL, 1958a).

\footnotetext{
1o As treze noções de classificação abordadas no livro Introdução à Técnica de Museus (BARROSO, 1953) são: Heráldica; Bandeiras; Condecorações; Armaria; Arte Naval; Viaturas; Arquiteturas; Indumentárias; Mobiliário; Cerâmica e Cristais; Ourivesaria, Prataria e Bronzes Artísticos; Máquinas e Instrumentos de Suplício.
} 
O conteúdo programático ministrado na $1^{\mathrm{a}}$ Seção - História foi interrompido no mês de setembro porque ocorreu na cidade do Rio de Janeiro, nesse período, o Seminário Regional Latino-Americano de Museus da Unesco com o tema A Função Educativa dos Museus. A equipe do Museu Histórico Nacional buscou aproximar as integrantes do curso de curta-duração do evento, pois os temas abordados convergiam, além do encontro internacional ser considerado, de antemão, um marco nos debates sobre educação em museus.

Realizado no Museu de Arte Moderna do Rio de Janeiro, no período de 7 a 30 de setembro de 1958, pelo registro da conservadora de museus Octavia Corrêa é possível verificar que as agências organizadoras do evento, UnescoIcom, autorizaram a presença das professoras-bolsistas como observadoras do Seminário, o que as possibilitou participarem dos debates, assistirem filmes sobre exposições e compartilharem as experiências de diferentes estudos de caso (BRASIL, 1958a). No relatório final do Seminário Regional Latino-Americano de Museus de 1958, organizado por Georges Henri Rivière ${ }^{11}$, há a menção de observadores brasileiros no evento por intermédio do Instituto Brasileiro de Educação, Ciência e Cultura (Ibecc), a fim de estender a influência do seminário no Brasil (RIVIÈRE, 1958).

Após a participação no Seminário Regional Latino-Americano de Museus da Unesco, as professoras-bolsistas deram sequência à formação na seção de Numismática. No relatório desta seção, não existem detalhes do encaminhamento do curso de curta-duração, apenas a informação de que as participantes ficaram de 1 a 31 de outubro de 1958 com a equipe da $2^{\text {a }}$ Seção Numismática, Filatelia e Sigilografia do Museu Histórico Nacional, sendo oferecidos conteúdos teóricos e aulas práticas sobre as coleções especializadas. Além disso, foram realizadas algumas visitas a museus e instituições com acervos relacionados à Seção, como a Casa da Moeda (BRASIL, 1958b).

\footnotetext{
${ }^{11}$ Georges Henri Rivière é um profissional de museu formado em 1928 na Escola do Louvre. Na ocasião do Seminário Regional Latino-Americano de Museus da Unesco era diretor do Conselho Internacional de Museus (1948-1965).
} 
No mês de novembro de 1958, as professoras-bolsistas retornaram para a $1^{\text {a }}$ Seção - História, a fim de dar prosseguimento ao $9^{\circ}$ tópico da programação, que tinha como foco o aprofundamento sobre coleções de viaturas, indumentária e cerâmica, além de aulas sobre catalogação e etiquetagem. Segundo a professora Octavia Corrêa, as participantes apreciaram muito as aulas ministradas, tirando delas os temas de trabalho de conclusão do curso, sob a forma de monografia, encaminhadas ao diretor do Inep (BRASIL, 1958a).

Em avaliação final da experiência vivenciada, a professora Octavia Corrêa ponderou que as professoras-bolsistas tiveram certa dificuldade de apreensão do conteúdo ministrado, mesmo as técnicas sendo ensinadas de forma amenizada, apontando como um possível motivo a turma ser composta por professoras primárias que não tiveram um contato prévio com os assuntos relacionados ao Curso de Museus. Como sugestão, foi indicado que as próximas versões ${ }^{12}$ do Curso de Organização dos Museus Escolares compreendessem um ano letivo, pois permitiria a realização de avaliações periódicas e estudos mais aprofundados, além de proporcionar maior segurança para o participante pelo seu envolvimento com as temáticas abordadas. Ainda assim, a equipe avaliou a execução do curso como uma experiência positiva, pois envolvera professores e funcionários na promoção de formação com qualidade e colaboração, permitindo a ambos compartilharem em seus horários esta proposta de ensino (BRASIL, 1958a).

\section{O CURSO DE MUSEUS ESCOLARES PELAS PROFESSORAS-BOLSISTAS}

$\mathrm{Na}$ documentação referente ao Curso de Organização dos Museus Escolares, localizado no Arquivo Institucional do Museu Histórico Nacional, foi

\footnotetext{
${ }_{12}$ Até o momento não foram encontradas evidências de outras edições do Curso de Organização dos Museus Escolares no Curso de Museus/Museu Histórico Nacional.
} 
possível encontrar a avaliação final das quatro professoras-bolsistas do Inep e o trabalho final de três dessas participantes. Suas monografias permitem ter um conhecimento mais aprofundado do conteúdo ministrado no curso de curtaduração, além de acompanhar como as habilidades e competências proporcionadas no Curso de Museus foram adaptadas para agentes que, aparentemente, tinham interesse em tornar-se profissionais de museus, mas não conservadoras diplomadas. Os docentes Octavia Corrêa, Yolanda Marcondes Portugal e Gerardo Alves de Carvalho foram os responsáveis pela avaliação geral das participantes. Em documento encaminhado à coordenadora do Curso de Museus é mencionado que as alunas ampliaram seus conhecimentos e experiências; tiveram interesse na temática central do curso; esforçaram-se para aprender e corresponder ao desafio de entrar em contato com as habilidades e competências propostas; compreenderam a relevância do museu escolar; aprenderam a realizar os procedimentos práticos de documentação museológica; tiveram bom aproveitamento do estágio; demonstraram interesse nos trabalhos letivos; foram assíduas; compareceram pontualmente às visitas indicadas; demonstraram compreensão do assunto e apresentaram sugestões aplicadas, entre outros aspectos mencionados (CORRÊA; PORTUGAL; CARVALHO, 1958, p. 1-2).

Os três trabalhos finais encontrados, de autoria das professoras-bolsistas Amélia Lucas Mattos (BA), Helena Ferreira Camargo (SP) e Maria Nadyr de Freitas (RS), possuem uma estrutura muito semelhante. As monografias possuem, respectivamente, 23, 33 e 21 páginas e todas foram entregues para avaliação no dia 24 de novembro de 1958. A organização textual dos trabalhos seguiu um padrão: Introdução; Museu - histórico, conceito e definição; Museu escolar - criação, finalidades e organização; Técnica de Museus; Conclusões.

Na introdução dos trabalhos é possível obter maiores detalhamentos da elaboração do Curso de Organização dos Museus Escolares. A professora-bolsista Helena Ferreira Camargo descreveu as motivações do Inep para solicitação dessa formação ao Museu Histórico Nacional e a importância da realização do curso de 
curta-duração por parte de funcionários da instituição e professores do Curso de Museus:

\begin{abstract}
Reconhecendo o valor dos museus na educação o Instituto Nacional de Estudos Pedagógicos instituiu, pela primeira vez no Brasil o curso de Organização dos Museus Escolares oferecendo, a seis estados da União, bolsas de estudo para o referido curso. [...] É de grande importância o referido curso e a criação de museus escolares, pois somente os grandes centros possuem museus que podem contribuir para a educação extracurricular dos escolares. O Museu Escolar contribuirá para um melhor aprendizado e também preparará o educando para apreciar e tirar o máximo de uma visita a um grande museu quando lhe apresentar uma oportunidade (CAMARGO, 1958, p. 1).
\end{abstract}

Percebe-se, pelo relato da professora-bolsista, que para a realização do curso de curta-duração estava prevista a inscrição de, no mínimo, seis participantes, uma vez que o Inep ofereceu bolsas de estudos para seis estados da União (CAMARGO, 1958). Destes, somente quatro encaminharam representantes: Bahia, Pernambuco, Rio Grande do Sul e São Paulo. Em nenhum documento encontrado até o momento consta a justificativa dessa média de participantes, sendo uma das possibilidades o caráter experimental da proposta. Uma das motivações relatadas para a vigência do curso era o desejo de ampliação de museus, como objetivo de contribuir para a educação extracurricular dos estudantes e com intenção de dispersar a concentração de museus nas capitais. Outra argumentação da professora-bolsista era a possibilidade de o museu potencializar o aprendizado do educando (Ibid.).

Ainda na Introdução, a professora-bolsista Helena Ferreira Camargo nos ofereceu pistas da distribuição de tarefas por parte dos docentes do curso. Pelo seu relato, confirma-se que os conservadores de museus Octavia Corrêa, Yolanda Marcondes Portugal e Gerardo Alves de Carvalho foram os responsáveis pelo curso de curta-duração, sob supervisão da conservadora de museus Nair de Moraes Carvalho. A professora Octavia Corrêa foi a responsável por ofertar aulas teóricas e práticas sobre Técnica de Museus; a professora Yolanda Marcondes 
Portugal ministrou noções de Numismática e as visitas orientadas ficaram sob responsabilidade do professor Gerardo Alves de Carvalho (CAMARGO, 1958).

No trabalho da professora-bolsista Amélia Lucas Mattos foi possível elencar as instituições visitadas no estado do Rio de Janeiro ao longo do curso, acompanhadas dos professores Yolanda Marcondes Portugal e Gerardo Alves de Carvalho ${ }^{13}$. Percebe-se que não há menção à visitação em museus escolares do Rio de Janeiro (MATTOS, 1958). A participante Helena Ferreira Camargo adicionou, além das visitas orientadas aos diversos museus da cidade, a ida a várias escolas padrão do Distrito Federal, porém, não há menção de que alguma dessas instituições escolares tivesse tal modalidade de museu (CAMARGO, 1958). No trabalho final da professora-bolsista Maria Nadyr de Freitas foi evidenciada a falta de conhecer in loco um Museu Pedagógico:

\begin{abstract}
Sentimos certamente, dadas as finalidades do curso, a falta de um Museu Pedagógico, na Capital da República, que deveria ser o centro natural de estudos, pesquisas e principalmente orientação para a organização dos museus escolares e resolução dos problemas que daí decorrem e que a orientação técnica que os museus oferecem não é suficiente para resolver (FREITAS, 1958, p. 3).
\end{abstract}

A observação acima é um importante relato sobre a relevância de um Museu Pedagógico na capital, que em décadas anteriores era representado pelo Pedagogium. Para a professora seria esta instituição a responsável por orientar os museus escolares e, inclusive, promover cursos como o que estava sendo adaptado no Museu Histórico Nacional. O Museu Pedagógico, em sua percepção, seria o mais capacitado a dar orientações técnicas de museus aplicadas no âmbito escolar (FREITAS, 1958).

Sobre a relação museu e educação, todas as participantes concordavam

\footnotetext{
13 Instituições visitadas: Museu Nacional de Belas Artes; Museu Nacional; Museu Imperial; Museu da Cidade; Museu de Geologia e Mineralogia; Museu de Caça e Pesca; Museu de Econômica Rural; Museu do Conselho Nacional; Museu de Geografia; Museu do Itamaraty; Museu do Banco de Brasil e Casa da Moeda (MATTOS, 1958).
} 
que os museus desempenhavam uma função educativa e que esse aprendizado deveria ser impulsionado. Os museus escolares seriam importantes para o processo de legitimação da educação em museus. Segundo a professora-bolsista Helena Ferreira Camargo:

\begin{abstract}
Até os fins do século XIX os museus se limitaram a conservação e classificação de objetos de arte, de história ou de ciências que só interessavam aos especialistas e conhecedores do assunto. Mas as concepções a respeito da função dos museus sofreram grandes transformações a partir do primeiro quarto deste século. E em nossos dias os museus aspiram realizar uma função social de informação e de cultura. São centros de grande valor na educação, pois um bom museu ajuda a se ter uma visão completa do mundo em que vivemos. Deixou de ser estático para ser dinâmico e além de recolher, conservar e expor os objetos é fonte de pesquisas e informações. Daí a definição atual de museu da autoria de Georges Henri Rivière. "Museu é um estabelecimento de caráter permanente, administrado para interesse geral, com a finalidade de conservar, estudar, valorizar de diversas maneiras e principalmente expor para deleite e educação do público, um conjunto de elementos de valor cultural" (CAMARGO, 1958, p. 3).
\end{abstract}

No texto acima, escrito pela professora-bolsista, percebem-se diversos indícios de afirmações que provavelmente são provenientes da apropriação das ideias disseminadas no curso de curta-duração. $\mathrm{O}$ discurso de que os museus sofreram grandes transformações no século XX, movimento que favoreceu essas instituições a não somente salvaguardar seus objetos, mas também potencializar seu papel educativo, era comum nesse período no campo dos museus. A evidência fica ainda mais latente quando é destacada a função social que os museus prestam à sociedade moderna, bem como a qualidade dos museus dinâmicos de serem fontes de pesquisas e conhecimento. Essas abordagens eram amplamente tratadas nos debates de eventos e publicações da época sobre educação em museus. A definição de museu de Georges Henri Rivière aparece em mais de um trabalho. A escrita da professora-bolsista Maria Nadyr de Freitas apresenta outros indícios que abordam, não somente a transformação dos museus no que tange à aprendizagem nesses espaços, mas, especialmente, a confluência entre os 
campos do museu e da educação na contemporaneidade:

Sendo de fundamental importância para o ensino, devia o Museu Escolar merecer mais atenção por parte de educadores e museólogos. [...] Tendo-se em conta a situação educacional em nosso país, em que a maioria faz apenas o curso primário, torna-se preciso que se procure despertar na criança, o amor pela cultura para que possa mais tarde procurar fora da escola, os meios de se instruir e educar. Sendo os Museus um dos maiores agentes da educação do povo, a iniciação nos museus é fundamental para atingir este desiderato e o Museu Escolar representa um importante ponto de partida para isto. A criança deve aprender a se "servir do museu". A vida coletiva pressupõe participação ativa e inteligente. É transmissão de experiências que resulta em aquisição de experiência. O magnífico acervo de material artístico, histórico e científico que os antigos nos legaram estão aí para serem utilizados para educar e instruir. [...] Daí a importância social e educativa dos museus. [...] $\mathbf{O}$ ensino ativo, em contato direto com a realidade, com experiências de trabalho, dá oportunidade ao aluno de exercitar sua tendência de agir, criando condições para seu desenvolvimento integral e seu ajustamento social (FREITAS, 1958, p. 1-2, grifo nosso).

No discurso acima é possível ver a atualização da professora em relação aos argumentos utilizados não só no campo dos museus, mas também por agentes e agências do campo da educação, para a legitimação da educação em museus. Há uma ênfase em seu discurso de que os museus seriam capazes de despertar o amor pela cultura e, consequentemente, instruir e educar seus visitantes. Ao considerar que, no período, a população brasileira tinha baixa escolaridade, creditava-se ao museu o desafio de despertar nas pessoas o interesse em aprender pela experiência e, em suas palavras, promover, consequentemente, o desenvolvimento e ajustamento social (FREITAS, 1958). Nesse sentido, o uso de expressões como educação do povo reforça o potencial que conferiam aos museus educar a população brasileira através da interação com o patrimônio coletivo.

Outro destaque é a atenção da professora-bolsista para o potencial dos museus como instrumentos do movimento de renovação do ensino. A participante menciona o ensino ativo e o caráter empírico que a aprendizagem 
nos museus proporciona sobretudo pela educação visual. Seu discurso está fundamentado no contato com o objeto que, portanto, oportunizaria a aquisição de experiências de cunho social. Pode-se concluir que, para a professora, o legado histórico, pelas evidências materiais, seria capaz de proporcionar ao indivíduo seu desenvolvimento e ajustamento social.

A professora-bolsista do estado do Rio Grande do Sul salientou que os museus escolares seriam relevantes para impulsionar a relação visitante-museu, pois despertaria na criança o primeiro contato e ao longo do ensino escolar as possibilidades de se "servir do museu" (FREITAS, 1958, p. 1). Nesse sentido, pode-se aferir pelos trabalhos que essa participante foi uma das mais opinativas em relação ao tema central do curso de curta-duração. A autora reforçou a necessidade de educadores e conservadores de museus darem mais atenção aos museus escolares; criticou a falta de um museu pedagógico na capital e, ainda, teceu proposições a partir de uma análise crítica feita ao Seminário Regional Latino-Americano de Museus da Unesco:

Embora os estudiosos em assuntos de Museu, como foi ventilado no Seminário Regional sobre "Função Educativa dos Museus", realizado no Rio de Janeiro, de 7 a 30 de setembro, do corrente ano, não tenham chegado a uma conclusão quanto à legitimidade e definição dos museus escolares, chamando a opinar os Centros Pedagógicos, não só nos arriscamos a afirmar sua legitimidade, como procuraremos defini-lo, traçando-lhe as finalidades.

\section{FUNÇÃO}

O Museu Escolar, de caráter geral e enciclopédico, tem organização própria e exerce suas atividades sob orientação pedagógica. Sua função é essencialmente educativa.

\section{FINALIDADES}

1 - Permitir a objetivação da aprendizagem pela apresentação do objeto real.

2 - Aproveitar todas as conquistas da técnica moderna, pela utilização dos recursos áudio-visuais.

3 - Dar ao professor, através do material didático, os meios necessários para atender os reclamos da técnica educativa. 
4 - Preparar o aluno para se servir do Museu, como fonte de formação e informação, com a participação ativa em suas atividades.

5 - Propiciar possibilidades de socialização do educando, desenvolvendo seu espírito de organização e cooperação, pela ação orientada, pela participação ativa e pelo trabalho de equipe.

6 - Promover a formação e o desenvolvimento integral do educando.

7 - Facilitar a motivação e a fixação da aprendizagem.

8 - Desenvolver o espírito de análise, a observação e o raciocínio, pela oportunidade de novas experiências.

9 - Estimular a frequência aos museus, indispensável à instrução e à educação da criança (FREITAS, 1958, p. 5-6).

Pelos apontamentos da professora-bolsista, é possível ter conhecimento de que alguns debates, no Seminário Regional Latino-Americano de Museus da Unesco, foram, em sua opinião, inconclusivos. Esse indício estimulou o retorno ao documento final do evento. $\mathrm{Na}$ quarta parte do relatório, organizado por Georges Henri Rivière, referente às conclusões do Seminário, um capítulo inteiro foi destinado ao tema museus e educação ${ }^{14}$. Nele há uma seção sobre Museus Escolares, composta por três subdivisões: Definição, funcionamento; Repercussões para o Icom; e Repercussões na América Latina (RIVIÈRE, 1958).

O subitem Definição, funcionamento é o que possui maior conteúdo, os demais contêm apenas um parágrafo. A primeira colocação realizada foi a de não confundir museus universitários com museus escolares. Essa segunda categoria foi definida como um estabelecimento sem uma estrutura especial, de nível modesto, com função exclusivamente de ensino, administrada por professores ou pela escola, e que congregaria uma simples reunião de materiais didáticos indispensáveis, uma pequena coleção, formada por reproduções, modelos e até mesmo objetos originais de diferentes assuntos que contribuiriam para ilustrar o ensino (RIVIÈRE, 1958).

\footnotetext{
${ }^{14} \mathrm{O}$ capítulo sobre museu e educação trata de tópicos como entidades educacionais; atividades didáticas; publicações e sua venda; películas; rádio; televisão; museus para a juventude; museus escolares; museus pedagógicos (RIVIÈRE, 1958).
} 
O texto final do evento internacional aponta que o museu escolar poderia fornecer um bom serviço, especialmente se os alunos participassem da formação das coleções. Sobre elas foi destacada a necessidade de limitações no que tange ao seu crescimento, pois a incorporação descontrolada de objetos traria desvantagens ao desenvolvimento do museu e sua utilização. A partir do texto, é possível conjecturar que os encaminhamentos do evento pontuavam advertências em relação aos museus escolares. Foi ressaltado que, para manter o acervo em boas condições, era necessário que as escolas destinassem um mínimo de recursos e cuidados ao museu. Coleções volumosas iriam necessitar de funcionários competentes para conservá-las. Enfatizou-se, ainda, que um museu escolar abandonado oferecia um triste cenário para o aprendizado escolar, muitas vezes consequência de um criador entusiasta que não encontrou outros professores ou apoio da escola para manter o projeto de museu (RIVIÈRE, 1958).

Os apontamentos sobre museus escolares, produzidos a partir dos debates promovidos no Seminário Regional Latino-Americano de Museus da Unesco, são um tanto curiosos. A redação final aparenta mais uma tentativa de conter essa experiência de museu do que incentivá-la, o que chama atenção em um evento que teve como tema central a função educativa dos museus. Pode-se sugerir que, na análise dos participantes, os exemplos de museus escolares que conheciam não contemplavam o que concebiam pela conceituação apresentada no evento, ou seja, função exclusivamente dos conteúdos curriculares. Na redação final, percebem-se dois extremos vinculados à categoria dos museus escolares: eram depósitos abandonados ou projetos que se equiparavam aos museus tradicionais.

Cabe ressaltar que os participantes do Seminário eram profissionais que atuavam no campo dos museus. Cada evento realizado pelos agentes e agências foi um movimento de legitimação do campo, certificação que incluiu hierarquias nas relações instituídas. Assim, não é de estranhar que a conservadora de museus e professora Octavia Corrêa expusesse dúvida sobre a finalidade do curso de curta-duração requisitado pelo Inep e questionasse a existência de museus 
escolares, no sentido estrito da palavra, na cidade do Rio de Janeiro. Possivelmente, a profissional partilhava da opinião registrada no evento internacional.

Nesse contexto, também não causa estranhamento a posição da professora-bolsista Maria Nadyr de Freitas. No Seminário da Unesco, ela estava na condição de observadora, não de participante. É em seu trabalho final do curso de curta-duração que demonstrou descontentamento quanto ao aspecto inconcluso da definição dos museus escolares. Essa categoria de museus se situava na interseção dos campos dos museus e da educação. Como autora do texto e, na posição de professora que atua no campo da educação, se "arrisca", como menciona, em afirmar a legitimidade dos museus escolares, defini-los e tecer suas finalidades.

No exercício, a professora-bolsista reforça que o museu escolar tem função educativa, indo ao encontro da definição do evento da Unesco. Das nove funções que elenca, oito são voltadas para atividades de divulgação do patrimônio. A divulgação ${ }^{15}$ tinha por finalidade estabelecer técnicas de apresentação dos objetos, nas exposições, promovendo experiências de aprendizagem pela educação visual (FARIA, 2017). O destaque desse trabalho estava nas diferentes propostas e recursos aplicados sugeridos pela professora, como a socialização do educando por meio de novas experiências, a facilitação da motivação e a fixação da aprendizagem e a utilização de audiovisuais na apresentação do objeto real. A vinculação da tipologia de museu escolar com o exercício de divulgação dos museus é também exaltada no trabalho de suas colegas de curso:

O museu escolar é de caráter especializado e só deverá funcionar com orientação pedagógica. O Museu Escolar será a apresentação completa e sistemática de material áudio-visual e coleções, destinados a dar uma forma concreta ao ensino porque só a experiência torna possível o

\footnotetext{
${ }^{15}$ A divulgação era também denominada no período de pesquisa educacional pelos conservadores
} de museus. Ver Faria (2017). 
conhecimento e compreensão das coisas. [...] A educação de nossa época dispõe de recursos maravilhosos, é uma educação áudio-visual que além das ilustrações impressas, coleções de museu, mapas, etc pode contar com os recursos do disco, da fita magnética, do diafilme, do cinema, do rádio e da televisão. [...] $\mathrm{O}$ museu escolar não se destina a visitação pública mas a professores, alunos das escolas onde funciona, a alunos de outras escolas primárias que não possuam museu e aos estudantes das Escolas Normais. Como veículo de cultura o museu deve ser visitado por alunos de todos os graus. O professor deverá orientar as visitas e estimular os alunos para que voltem ao museu para observar melhor, porque a experiência tem demonstrado que de um certo modo repetir é aprender (CAMARGO, 1958, p. 4-5).

A redação acima, de autoria da professora-bolsista Helena Ferreira Camargo, reforça o papel dos museus de divulgar o conhecimento pelo contato com os vestígios materiais. Os recursos audiovisuais contribuiriam para estimular o aprendizado através da experiência concreta. Percebe-se que essa proposta era direcionada às necessidades da comunidade escolar, conferindo à tipologia um caráter especializado. A professora-bolsista Amélia Lucas Mattos também reforçou a importância da criação dos museus escolares como forma de proporcionar melhor aprendizado (MATTOS, 1958).

Para as professoras-bolsistas do Inep o papel dos museus, em especial dos museus escolares, estava em consonância com os profissionais de museus que atuavam ou circulavam no campo dos museus no período investigado, em especial os educadores. Muitos desses agentes se interessavam pelos instrumentos considerados aparelhamentos modernos de educação, como os museus, radiodifusão e cinema educativo, a exemplo dos educadores Edgard 
Roquette-Pinto ${ }^{16}$, Edgar Süssekind de Mendonça17 e Francisco Venancio Filho ${ }^{18}$. O museu, através de sua atribuição de divulgação, seria capaz de promover experiências de compreensão das coisas, segundo as professoras-bolsistas.

As professoras-bolsistas do Inep estabeleceram, nos relatórios, duas frentes de trabalho para que as finalidades do museu escolar fossem viabilizadas em sua plenitude: a parte técnica e a parte pedagógica. A primeira contemplaria a parte geral da técnica de museus apresentadas no livro Introdução à Técnica de Museus (BARROSO, 1951): organização; arrumação; catalogação; e restauração de monumentos e objetos. As professoras-bolsistas acrescentaram, ainda, a classificação, parte especializada que compreende o segundo volume da referida obra (Id., 1953). Caberia à parte pedagógica, como a professora Helena Ferreira Camargo listou, dar assistência aos visitantes; orientar a participação dos alunos no museu escolar; organizar excursões, palestras, sessões educativas, projeções fixas, reuniões cívicas e recreativas; além de dar publicidade às atividades do museu (CAMARGO, 1958).

Em relação à parte da técnica de museus, dois assuntos se destacam nos relatórios: a catalogação e a arrumação. No livro Introdução à Técnica de Museus (1951), Gustavo Barroso ensinava os alunos do Curso do Museus e seus leitores a padronizar a numeração de inventários, confeccionar etiquetas e elaborar fichários. Esses recursos foram também ensinados para as professoras-bolsistas do Inep, compreendendo as seguintes etapas: inventário; classificação;

16 Edgard Roquette-Pinto era médico legista, professor, antropólogo, etnólogo, escritor e arqueólogo. Em 1905 tornou-se, por concurso, professor assistente de Antropologia e Etnografia no Museu Nacional. Foi diretor do Museu Nacional no período de 1926 a 1935. Roquette-Pinto foi o primeiro diretor do Instituto Nacional de Cinema Educativo (Ince), criado em 1936, permanecendo no cargo até 1947. Para maiores informações de sua trajetória profissional, disponível em: http://cpdoc.fgv.br/sites/default/files/verbetes/primeira-republica/roquettepinto.pdf. Acesso em: jan. 2018.

${ }_{17}$ Edgard Sussekind de Mendonça teve a vida marcada pela dedicação à educação. Participou da criação da Associação Brasileira de Educação (ABE) e foi um dos signatários do Manifesto dos Pioneiros da Escola Nova (SOUZA, 2011).

${ }^{18}$ Formou-se em Engenharia Civil. Participou ativamente na Associação Brasileira de Educação (ABE), e foi um dos signatários do Manifesto dos Pioneiros da Escola Nova (1932) (ESTEVES, 1994). 
etiquetagem e numeração.

Percebe-se, através dos relatórios finais, que a catalogação foi ensinada como um trabalho prático e metodológico. A professora Maria Nadyr de Freitas (1958) elencou três conjuntos de recursos necessários para a catalogação nos museus escolares: livros para inventário, movimentação, registro de visitas, aulas e atas; fichas históricas, pedagógica, de tombamento, para biblioteca e filmoteca; pastas para correspondências recebidas e expedidas, recibos, instruções e diversos. De acordo com a professora Helena Ferreira Camargo (1958), o professor encarregado de classificar o material precisava ter conhecimento de cada matéria escolar e da aplicação dos objetos nas aulas. Essas informações contribuiriam para o inventário, catalogação e etiquetagem das coleções.

Ao analisar as três monografias, identificou-se que o tema classificação e pesquisa do acervo não foi muito aprofundado pelas professoras-bolsistas do Inep, embora constasse, na ementa do curso de curta-duração, um tópico exclusivo para classificação de acervo com ênfase nas tipologias pintura e gravura, cerâmica, indumentária, armaria e viaturas (BRASIL, 1958a). O discurso recorrentemente encontrado pode ser exemplificado pelas palavras da professora Amélia Lucas Mattos (1958, p. 11-12):

\footnotetext{
CLASSIFICAÇÃO

O trabalho de classificação é sem sombra de dúvida o trabalho mais difícil e importante do museu. Toda peça ao chegar ao museu será rigorosamente classificada. No Museu Escolar, o classificador, além de grande soma de conhecimentos deverá ter o conhecimento profundo da metodologia das diferentes matérias que constituem o programa escolar a fim de fazer uma boa classificação.
}

A professora Maria Nadyr de Freitas, em seu relatório, tem discurso muito semelhante ao descrito acima, ao enfatizar que o procedimento requer, do classificador, conhecimentos especializados, teóricos, técnicos e práticos. A participante amplia a análise ao afirmar que nos museus escolares, além das 
noções sobre as tipologias de acervos, faz-se também necessário que o classificador tivesse conhecimentos gerais de métodos pedagógicos atuais, problemas escolares e conhecimentos especiais sobre as áreas de ensino (FREITAS, 1958). A professora Helena Ferreira Camargo (1958) é a que mais adapta a classificação de acervo às necessidades de um museu escolar ao exercitar essa adaptação (Fig. 1):

Figura 1 - Exemplo de catalogação aplicado aos museus escolares, 1958.

\begin{tabular}{|c|c|c|c|c|}
\hline $\begin{array}{r}\text { Natureza do } \\
\text { Material }\end{array}$ & Material & Matéria & Assunto & Grau \\
\hline Auditivo & D1scos & Canto & Dia das mães & Pró \\
\hline Recreativo & Bolar & Bduc. PÍsica & Jogo日 & 12 ano \\
\hline Manipulativo & Grav. 22 tipo & Iinguagem & Narraçã。 & 22 ano \\
\hline Manipulativo & $\begin{array}{l}\text { Mapa } \\
\text { Mapa madoulo }\end{array}$ & Geografia & Rio Tiets & 39 ano \\
\hline Projetivo & $\begin{array}{l}\text { Quadros hist. } \\
\text { diafilmes }\end{array}$ & Hist. Brasil & Desc. Brasil & 42 ano \\
\hline Manipulativo & $\begin{array}{l}\text { Moedas }{ }^{e} \\
\text { papel moeda }\end{array}$ & Aritmética & $\begin{array}{l}\text { Sist. Monet. } \\
\text { brasileiro }\end{array}$ & 52 ano \\
\hline
\end{tabular}

Fonte: Camargo (1958, p. 9).

Percebe-se, pela Figura 1, que a professora Helena Ferreira Camargo (1958) realizou um ajustamento da classificação de acervos para as possíveis necessidades e características dos museus escolares, subdividindo o material em quatro frentes: manipulativo, projetivo, auditivo e recreativo. A professorabolsista elenca para cada conjunto diversos exemplos de possíveis objetos referentes àquela natureza, mas não apresenta detalhamentos sobre os indícios relacionais a serem mapeados em cada materialidade. A ausência da imersão, nesse procedimento, reforça que, possivelmente, o tema da classificação fora o abordado com maior superficialidade pela professora Octavia Corrêa. A classificação e a pesquisa foram consideradas atividades árduas de serem assumidas com protagonismo pelos conservadores de museus. 
Se a classificação e pesquisa foram procedimentos tratados de forma incipiente pelas professoras-bolsistas do Inep em seus relatórios finais, o mesmo não se pode dizer quanto ao tema arrumação. $\mathrm{O}$ assunto ganhou, nos relatórios, de duas a cinco páginas que enfocam suas características, objetivos, recursos e estratégias. De acordo com a professora Maria Nadyr de Freitas:

\section{ARRUMAÇÃO}

A apresentação é muito importante num museu e, principalmente num museu escolar que deve obedecer a requisitos especiais.

O museu apresenta o objeto em si mesmo, embora fora do seu 'habitat'. Cabe ao educador abrir o caminho que leva o aluno a este objeto do qual deverá captar uma mensagem. $\mathrm{O}$ ensino exige que se ponha o aluno em contato com a realidade material ou humana que é objeto de estudo de cada disciplina.

A apresentação que tem de ser discreta é, ao mesmo tempo, educativa e recreativa e deve atingir sua finalidade. Exige, portanto, um planejamento muito cuidado [sic], em que os conhecimentos pedagógicos e museológicos se combinam e se completam.

A estética da apresentação não pode ser esquecida num museu escolar, assim como a originalidade, muito importantes para a formação do educando (FREITAS, 1958, p. 9).

No texto acima, é possível identificar muitas ideias que estavam em debate na primeira metade e em meados do século XX, no campo dos museus, sobre a divulgação do patrimônio. Percebe-se a valorização da apresentação do acervo nas exposições, que a professora posteriormente classifica em permanentes, temporárias e especializadas. Independentemente do tipo de exposição, esta deveria apresentar, em suas palavras: originalidade; estética; discrição e planejamento adequado (FREITAS, 1958). Temas como seleção e abarrotamento, muito debatidos nos eventos promovidos no campo, também foram abordados no curso de curta-duração:

A seleção dos objetos e coleções a serem expostos e a sua arrumação nas vitrinas requer bom gosto, originalidade e inteligência do dirigente do 
museu. A arrumação deve ser feita de modo a valorizar as peças expostas; deve ser simples e atraente, pois o acúmulo destrói o valor pedagógico dos objetos. [...] Uma boa exposição de objetos deve seguir os seguintes princípios:

1) Efeito estético dos próprios objetos.

2) Efeito estético de (uma) colocação.

3) Facilidade de visão e exame pelo público.

4) Boa e clara etiquetagem.

5) Proteção dos objetos contra as intempéries.

6) Defesa dos mesmos contra descuidos do visitante (CAMARGO, 1958, p. 16-17).

O texto da professora Helena Ferreira Camargo (1958) evidencia não somente os últimos debates sobre divulgação e educação em museus realizados no período, mas, também, a leitura do livro Introdução à Técnica em Museus (1951) em relação à arrumação dos museus. Os princípios por ela elencados são os concebidos por Gustavo Barroso como indeclináveis para uma boa exposição. O aprofundamento desse procedimento, no curso de curta-duração, foi tão mais expressivo que é possível apreciar, inclusive, modelos de vitrines exemplificadas pelas professoras-bolsistas (Fig. 2):

Figura 2 - Modelos de vitrine para museus escolares, 1958.

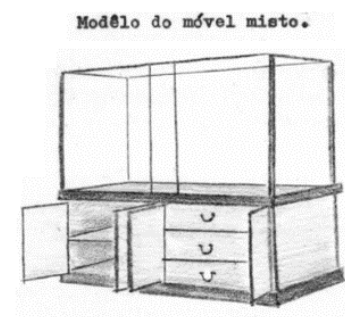

Medidas para o armário misto. 1,50m largura do armário $1,40 \mathrm{~m}$ " da vitrina 1,80m altura total

$0,80 \mathrm{~m} "$ do armár10

$1,00 \mathrm{~m}$ - da vitrina

0,65 m profundidade do armário $0,60 \mathrm{~m} \quad$ da vitrina
Modelo da vitrina central.

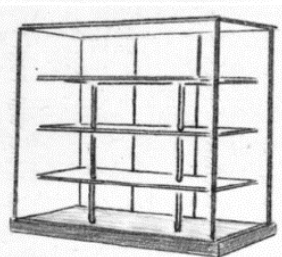

Medicas para vitrine central.

$1,80 \mathrm{~m}$ al tura total

0,20 m al tura da base

$1,60 m$ " da vitrina

$2,00 \mathrm{~m}$ a $2,50 \mathrm{~m}$ de largurs

2,00m larg. da base $\times 0,70 \mathrm{~m}$ profundidade

$1,90 m$ " da vitrina $\times 0,60 m$ profundidad

$2,50 \mathrm{~m} "$ "da bese $\times 0,70 \mathrm{~m}$ "

$2,40 \mathrm{~m} "$ da vitrina $\mathrm{x} 0,60 \mathrm{~m}$

3 prateleiras de vidro eom $0,40 \mathrm{~m}$ de espaço
Modelo para mesa-vitrina.

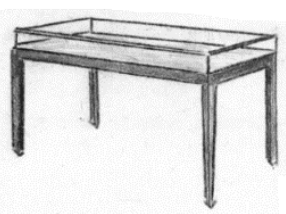

Medidas para mesa-vitrina.

$0,90 \mathrm{~m}$ altura total

$0,80 \mathrm{~m}$ " da mesa

$0,10 \mathrm{~m}$ " da vitrina

1,00 m comprimento da mesa

0,80 m largura da mesa

Fonte: Camargo (1958, p. 18-20). 
Pode-se dizer, pelos exemplos acima, que o envolvimento das professoras-bolsistas do Inep, com a técnica de museus, priorizou a organização de museus escolares em sua totalidade, com especial atenção para a divulgação do patrimônio escolar. Ao longo do trabalho final das participantes fica evidente que os museus escolares contribuíam para um ensino mais ativo e participativo e que as exposições ganhavam destaque nessa proposta. As múltiplas possibilidades de atividades educativas, vinculadas aos museus escolares, são apontadas nas conclusões da professora Maria Nadyr de Freitas (1958, p. 19):

\begin{abstract}
O Museu Escolar deve ser o centro dinâmico das atividades escolares, respondendo às necessidades do ensino que deve ser ativo, dando ao professor o recurso necessário ao seu trabalho. Embora possua coleções deve ser, ao mesmo tempo, atelier e classe, com estúdio, sala de projeção, atividades áudio-visuais, trabalho infantil, fantoches, marionetes, etc., despertando nos educandos o espírito de organização e de equipe, o sentimento artístico e o senso social. [...] A organização de clubes culturais e recreativos é também tarefa dos museus escolares, como os Clubes de História Natural, de Folclore, de Economia, Cineclubes, Radioclubes, etc.
\end{abstract}

Para essas propostas efetivamente ocorrerem nas escolas, por intermediação dos museus escolares, as professoras-bolsistas exaltavam a necessidade dos gestores escolares terem uma iniciação em técnica museológica, seja por meio de cursos, palestras ou estágios, além de ter a referência do Museu Pedagógico. A professora Maria Nadyr de Freitas (1958) sugere uma estrita cooperação dos museus tradicionais com os museus escolares. Todas, em algum momento de seus textos, apontam que professores com formação especializada em Museologia dariam a contribuição necessária para o desenvolvimento dos museus escolares (CAMARGO, 1958; FREITAS, 1958; MATTOS, 1958). 


\section{CONSIDERAÇÕES FINAIS}

As informações aqui analisadas sobre a organização do Curso de Museus Escolares pelo Museu Histórico Nacional, nos anos 1950, demonstram que os museus e o sistema de ensino continuavam em diálogo, para além do século XIX e primeiras décadas do século $\mathrm{XX}$, no que se refere à montagem de museus escolares. Nessa experiência, o protagonista não era mais um museu de ciências, mas um museu de viés histórico que consolidava seu papel como formador de profissionais no campo da Museologia. Nesse sentido, compreende-se a procura da instituição pelo Inep para oferecer uma formação às professoras para que estas viessem a assumir a tarefa de organização de museus em suas escolas.

Pelos relatórios finais, é possível supor que as professoras-bolsistas do Inep tiveram um bom aproveitamento do Curso de Organização de Museus Escolares. Percebeu-se que a proposta final das professoras foi não somente ampliar essa categoria de museus, mas sobretudo, reforçar as potencialidades da relação escola (visitante) e museu (patrimônio cultural) a partir da educação visual. Nesse sentido, visitar os museus era tão expressivo quanto criar esses espaços nas escolas.

Cabe como futuro andamento da pesquisa identificar os itinerários das professoras-bolsistas, especialmente após o retorno a seus respectivos estados e instituições de ensino nas quais atuavam. Uma das indagações centrais que emergem do trabalho é analisar possíveis desdobramentos do curso de curta duração, a exemplo da criação de museus escolares ou diretrizes de gerenciamento institucional disseminados pelas participantes. O trabalho de seleção, classificação, catalogação, pesquisa e interpretação do objeto foi exaltado no Curso de Organização de Museus Escolares como um processo para a produção de conhecimento sobre a materialidade exposta, valorizando, sobretudo, a educação visual. Ainda que seja um desafio encontrar reminiscências da difusão do aprendizado especializado transmitido às professoras-bolsistas, a realização do curso de curta duração insere-se como uma 
relevante iniciativa conjugada na década de 1950 para fortalecer e qualificar a educação visual através de uma das manifestações de confluência dos campos dos museus e da educação: os museus escolares.

Ressalta-se que no ano da escrita desse trabalho, 2018, ocorrem exatos 60 anos que a primeira edição do Curso de Organização de Museus Escolares foi ministrada nas dependências do Museu Histórico Nacional e, concomitantemente, realizado o Seminário Regional Latino-Americano de Museus. O campo dos museus e da educação estavam, naquele ano, envolvidos com o tema educação em museus e a participação brasileira teve amplo engajamento nas reflexões teórico-metodológicas oportunizadas, especialmente, pela organização de um evento internacional da Unesco, com parceria do Icom, no Brasil. O Seminário Regional Latino-Americano de Museus gerou um movimento local de produção temática. Livros publicados em 1958 como dos conservadores de museus Guy de Hollanda, Reginal Real e Florisvaldo Trigueiros, matérias de jornais - a exemplo do Correio da Manhã, que cobriram os preparativos do evento -, e envolvimento do Ibecc na organização do Seminário estimularam profissionais a legitimarem os museus como um espaço que tem por função promover a educação visual.

Tendo em vista o contexto da realização do Curso de Organização de Museus Escolares, é possível sugerir que a parceria entre o Inep e o Curso de Museus do Museu Histórico Nacional também tenha se estabelecido pelas motivações de 1958. Este se tornou um ano propício para novas iniciativas voltadas para educação em museus e, nesse recorte, os museus escolares. O projeto piloto visava não somente promover debates teóricos, mas, principalmente, estimular uma ação empírica que pudesse causar impacto em uma política voltada para a gestão nacional e estadual de museus escolares.

Cabe concluir que, embora o curso promovido tivesse um conteúdo especializado, as professoras-bolsistas tiveram um forte engajamento com a inciativa proposta, demonstrando esforço em se apropriar dos conceitos, debates e práticas próprias do campo dos museus para aplicá-los, posteriormente, em 
suas escolas. Não temos, ainda, pistas sobre a perpetuação da formação realizada nos estados de origem das participantes e, consequentemente, suas repercussões em nível local. Isso já é tema para uma nova pesquisa.

\section{REFERÊNCIAS}

BARROSO, Gustavo. Introdução à técnica de museus. Rio de Janeiro: Ministério da Educação e Saúde; Olímpica, 1951.

BARROSO, Gustavo. Introdução à técnica de museus. Rio de Janeiro: Ministério da Educação e Saúde; Olímpica, 1953.

BASTOS, Maria Helena Camara. Pro Patria Laboremus: Joaquim José de Menezes Vieira (1848-1897). Bragança Paulista, SP: Edusf, 2002.

BERRIO, Julio Ruiz. Hacia una tipología de los museos de educación. In: El libro y la educación. Alcalá de Henares: Asociación Nacional de Editores de libros y material de enseñanza/Anele, 2000.

BRASIL. Ministério da Educação e Cultura. Museu Histórico Nacional. $\mathbf{1}^{\mathbf{a}}$ Seção de História - 1958. Rio de Janeiro, 1958a. 3 fl. [Ofício anexado ao relatório anual. Enviado no dia 18 de novembro de 1958].

BRASIL. Ministério da Educação e Cultura. Museu Histórico Nacional. Relatório Anual do Museu Histórico Nacional em 1958. Rio de Janeiro, 1959. $31 \mathrm{p}$.

BRASIL. Ministério da Educação e Cultura. Museu Histórico Nacional. Relatório da Seção de Numismática - 1958. Rio de Janeiro, 1958b. 26 p.

CAMARGO, Helena Ferreira. Organização de museu escolar. 1958. 33 f. Monografia (Curso de Organização de Museus Escolares) - Rio de Janeiro, 1958.

CERTEAU, Michel. A escrita da história. 3. ed. Rio de Janeiro: Forense, 2011.

CORREA, Octavia; PORTUGAL, Yolanda Marcondes; CARVALHO, Gerardo Alves de. [Ofício] Sra. Coordenadora do Curso de Museus do Museu Histórico Nacional. 28 nov. 1958, Rio de Janeiro, [para] Nair de Moraes Carvalho, Rio de Janeiro. 2 fls. [Sobre avaliação final das professoras-bolsistas do Curso de Organização de Museus Escolares]. 
ESTEVES, Fernando Segismundo. Venancio Filho, Fernando de Azevedo e Euclides da Cunha. Revista da Faculdade de Educação, 21 p., 1994. Disponível em: https://www.revistas.usp.br/rfe/article/view/33538. Acesso em: jan. 2018.

FARIA, Ana Carolina Gelmini de. Educar no museu: o Museu Histórico Nacional e a educação no campo dos museus (1932-1958). 2017. 292 f. Tese (Doutorado) - Programa de Pós-Graduação em Educação, Universidade Federal do Rio Grande do Sul, Porto Alegre, 2017.

FARIA, Ana Carolina Gelmini de. O caráter educativo do Museu Histórico Nacional: o Curso de Museus e a construção de uma matriz intelectual para os museus brasileiros (1922-1958). 2013. 234 f. Dissertação (Mestrado) - Programa de Pós-Graduação em Educação, Universidade Federal do Rio Grande do Sul, Porto Alegre, 2013.

FONTAINE, Alexandre; MATASCI, Damiano. Centraliser, exposer, diffuser: les musées pédagogiques et la circulation des savoirs scolaires en Europe (18501900). Revue Germanique International, n. 21, p. 65-78, 2015.

FREITAS, Maria de Nadyr de. Organização de museu escolar. 1958. 21 f. Monografia (Curso de Organização de Museus Escolares) - Rio de Janeiro, 1958.

GARCÍA, Susana V. Museos escolares, colecciones y la enseñanza elemental de las ciencias naturales en la Argentina de fines del siglo XIX. História, Ciências, Saúde, Manguinhos, v. 14, n. 1, p. 173-196, 2007.

GINZBURG, Carlo. Mitos, emblemas e sinais: morfologia e história. São Paulo: Companhia das Letras, 1989.

HOLLANDA, Guy de. Recursos educativos dos museus brasileiros. Rio de Janeiro: CBPE-Onicom, 1958.

LINARES, Maria Cristina. Educar con los objetos: museos pedagógicos en la historia de la educación argentina (1880-2009). Buenos Aires: Universidad Nacional de Luján, 2012.

LOPES, Maria Margaret. Brasil descobre a pesquisa científica. São Paulo: Hucitec, 1997.

MATTOS, Amélia Lucas. Organização de museu escolar. 1958. 23 f. Monografia (Curso de Organização de Museus Escolares) - Rio de Janeiro, 1958.

MIGNOT, Ana Chrystina (org.). Pedagogium: símbolo da modernidade educacional republicana. Rio de Janeiro: Quartet; Faperj, 2013. 
PETRY, Marilia Gabriela. Da recolha à exposição: a constituição de museus escolares em escolas públicas primárias de Santa Catarina (Brasil - 1911 a 1952). 2013. 222 f. Dissertação (Mestrado) - Programa de Pós-Graduação em Educação, Centro de Ciências Humanas e da Educação, Universidade do Estado de Santa Catarina, Florianópolis, 2013.

POSSAMAI, Zita Rosane. "Lição de Coisas" no museu: o método intuitivo e o Museu do Estado do Rio Grande do Sul, Brasil, nas primeiras décadas do século XX. Arquivos Analíticos de Políticas Educativas, v. 20, n. 43, 2012.

POSSAMAI, Zita Rosane. Exposição, coleção, museu escolar: ideias preliminares de um museu imaginado. Educar em Revista, Curitiba, n. 58, p. 103-119, 2015a.

POSSAMAI, Zita Rosane. Olhares cruzados: interfaces entre história, educação e museologia. Museologia \& Interdisciplinaridade, Brasília, n. 6, p. 17-31, 2015b.

POSSAMAI, Zita Rosane; PAZ, Felipe Rodrigo Contri. Pesquisar e ensinar: considerações sobre museus escolares de ciências, Brasil e Argentina. In: GRANATO, Marcus; RIBEIRO, Emanuela Sousa; ARAÚJO, Bruno Melo de (org.). Cadernos do Patrimônio da Ciência e Tecnologia: instituições, trajetórias e valores. Rio de Janeiro: Museu de Astronomia e Ciências Afins, 2017. p. 283-307.

POUCET, Bruno. Les musées d'éducation. Musées \& Collections Publiques de France, n. 206, p. 12-17, 1996.

REAL, Regina Monteiro. Museu ideal. Belo Horizonte: Faculdade de Direito da Universidade de Minas Gerais e do Centro Regional de Pesquisas Educacionais, 1958.

RIVIÈRE, Georges Henri (org.). Seminario regional de la Unesco sobre la función educativa de los museos. Unesco/Icom, 1958.

SÁ, Ivan Coelho; SIQUEIRA, Graciele Karine. Curso de Museus - MHN, 1932-1978: alunos, graduandos e atuação profissional. Rio de Janeiro:

Universidade Federal do Estado do Rio de Janeiro, Escola de Museologia, 2007. $258 \mathrm{p}$.

SANJAD, Nelson. A Coruja de Minerva: o Museu Paraense entre o Império e a República (1866-1907). Rio de Janeiro: Ibram/Fiocruz, 2011.

SCHWARCZ, Lilia Moritz. O espetáculo das raças: cientistas, instituições e 
questão racial no Brasil, 1870-1930. São Paulo: Companhia das Letras, 2005.

SILVA, Camila Marchi; BRAGHINI, Katya. Museu Paulista, a instrução pública, e o provimento de materiais para as escolas do estado de São Paulo: uma história dos museus escolares. In: GRANATO, Marcus; RIBEIRO, Emanuela Sousa; ARAÚJO, Bruno Melo de (org.). Cadernos do Patrimônio da Ciência e Tecnologia: instituições, trajetórias e valores. Rio de Janeiro: Museu de Astronomia e Ciências Afins, 2017. p. 255-282.

SILY, Paulo Rogério Marques. Práticas educativas do Museu Nacional do Rio de Janeiro no início do século XX. In: CONGRESSO DA SOCIEDADE BRASILEIRA DE HISTÓRIA DA EDUCAÇÃO, 5., 2008, Aracajú/SE. Anais [...] Aracajú: UFSE/Unit, 2008. 15 p.

SOUZA, Natália Peixoto Bravo de. O papel dos euclidianos cariocas na monumentalização de Euclides da Cunha. In: SIMPÓSIO NACIONAL DE HISTÓRIA - ANPUH, 16., 2011, São Paulo. Anais [...] São Paulo: Anpuh, jul. 2011. 19 p.

TRIGUEIROS, Florisvaldo dos Santos. Museu e educação. Rio de Janeiro: Pongetti, 1958.

VIDAL, Diana Gonçalves. Museus pedagógicos e escolares: inovação pedagógica e cultura material escolar no Império Brasileiro. In: ALVES, Claudia; MIGNOT, Ana Chrystina (org.). História e historiografia da educação iberoamericana: projetos, sujeitos e práticas. Rio de Janeiro: Quartet; Faperj; SBHE, 2012. p. 197-211.

VIDAL, Diana Gonçalves. Por uma pedagogia do olhar: os museus escolares no final do século XIX. In: VIDAL, Diana Gonçalves; SOUZA, Maria Cecília Cortez Christiano (org.). A memória e a sombra: a escola brasileira entre o Império e a República. Belo Horizonte: Autêntica, 1999. p. 107-116.

VIÑAO FRAGO, Antonio. Historia de la educación y historia cultural: posibilidades, problemas, cuestiones. Revista Brasileira de Educação, n. o, p. 63-82, 1995 .

WITT, Nara Beatriz; POSSAMAI, Zita Rosane. Ensino e memória: os museus em espaço escolar. Cadernos do Ceom, v. 29, n. 44, jun. 2016. Disponível em: http://bell.unochapeco.edu.br/revistas/index.php/rcc. Acesso em: 31 jan. 2018. 
ANA CAROLINA GELMINI DE FARIA é bacharel em Museologia, doutora em Educação e professora adjunta da Universidade Federal do Rio Grande do Sul (UFRGS), atuando no Curso de Museologia/Faculdade de Biblioteconomia e Comunicação (Fabico) e no Programa de Pós-Graduação em Museologia e Patrimônio/UFRGS, em Porto Alegre/RS.

E-mail: carolgelmini@hotmail.com

(D) http://orcid.org/0000-0003-0727-9991

ZITA ROSANE POSSAMAI é doutora em História e professora associada da Universidade Federal do Rio Grande do Sul (UFRGS), atuando no Curso de Museologia/Faculdade de Biblioteconomia e Comunicação (Fabico) e nos Programas de Pós-Graduação em Educação e em Museologia e Patrimônio/UFRGS, em Porto Alegre/RS.

E-mail: zitapossamai@gmail.com

(D) http://orcid.org/0000-0003-4014-5389

Recebido em: 07 de fevereiro de 2018

Aprovado em: 07 de janeiro de 2019

Revista História da Educação - RHE

Associação Sul-Rio-Grandense de Pesquisadores em História da Educação - Asphe

Artigo de acesso aberto distribuído nos termos de licença Creative Commons. 